work, consisting of distinctive permanent marks at suitable intervals and engraved with precise position, height and other relevant data to serve as a local starting point for surveys of all kinds.

\section{Agricultural Policy in Jamaica}

THE report of the Agricultural Policy Committee of Jamaica appointed in May 1944 has now been published (Kingston, Jamaica : Dept. of Agriculture. 1s.). The terms of reference were wide, including the definition of a policy for the utilization of land resources, a policy for agricultural development, proposals for co-operation between producers and the Government, and the co-ordination of all Government services concerned with rural development. Jamaica is entirely dependent on the land for sustenance, and there are no manufactures based on imports of raw material. The total available land is inadequate for the needs of the present population, quite apart from the fact that much of the land has been misused and that the capital essential for large-scale re. habilitation is lacking. In its report, the Committee shows the urgency of the situation and puts forward a number of specific proposals to remedy it. Among the recommendations made is the establishment of a land authority for the purpose of bringing all land into proper use, and the suggestion that relief employment should be directed into productive channels, such as improvement in water supplies, soil conservation or afforestation. Emphasis is also laid on the need for progressive policies on questions of housing and education. As regards economics, colonial preference and long-term guarantees as to markets and prices are considered essential for the future prosperity of Jamaica, while to promote a general increase in efficiency, practical proposals are brought forward for improving organisation and co-ordination of Government departments.

\section{Field Tests of Paludrine}

Some preliminary results of the effects of paludrine, the new synthetic antimalarial drug (see Nature, 156, $596 ; 1945$; and 157,$128 ; 1946$ ), are reported in the Lancet (Feb. 23, p. 278). Brigadier Hamilton Fairley and his colleagues in Australia have fully confirmed the results of studies made in England, and their work indicates that small daily doses of paludrine effectively suppress both benign tertian and malignant tertian malaria. Benign tertian malaria, however, developed in some subjects who were receiving daily doses of paludrine for three weeks after the last bites of the infected mosquitoes. A single dose of paludrine given weekly for an indefinite time after the primary attack of malaria has been controlled will prevent relapses of benign tertian malaria until it is eradicated. The fact that paludrine is an effective clinical cure of attacks of benign tertian, malignant tertian and quartan malaria was also confirmed. Paludrine did not, however, prevent the production of gametocytes of either Plasmodium vivax (benign tertian malaria) or $P$. falciparum (malignant tertian malaria), the structure and number of which were not materially altered by it. Nevertheless, the gametocytes did not mature when they were taken in by mosquitoes from subjects who were receiving paludrine, although, a week after the drug was discontinued, the gametocytes could infect mosquitoes. In addition to this, when mosquitoes were allowed to feed on a subject who was taking paludrine and then were allowed to complete their meal upon a subject who was harbouring gametocytes but was not taking paludrine, the mos. quitoes did not become infected. This suggests, the Lancet says, that paludrine acts upon the early stages of development of the malarial parasites in the mosquito. This action on the developmental stages in the mosquito did not occur when the mosquito had been infected some days before the meal of blood taken from the subject who was receiving paludrine. One interesting result obtained was the observation that 200 c.c. of blood taken from subjects known to be infected with benign tertian malaria did not infect volunteers while the donors were taking paludrine. Quinine and mepacrine will not prevent infection in similar circumstances. A re-examination of the toxicity of paludrine has shown that, within the wide range of effective dosage, its toxicity is negligible. The volunteers from the Australian Forces who allowed themselves to be experimentally infected and so made possible the work at the Australian Army Medical Research Institute at Cairns, Queensland, deserve our deepest gratitude.

\section{Medical Use of Sulphonamides}

THE second edition of the Medical Research Council's War Memorandum No. 10, entitled "The Medical Use of Sulphonamides". (H.M. Stationery Office, 1945. 1s. 3d. net), by various authors and edited by F. Hawking and F. H. K. Green, incorporates the advances made since the first edition was published in 1943 in our knowledge of the uses of sulphonamides, and includes sections on the use of three of the many sulphonamides which have been introduced since the first edition of the memorandum was printed. These are sulphamerazine, phthalylsulphathiazole (also called sulfathalidine; see also Lancet, 544, April 22, 1944) and marfanil (also called sulphabenzamine, which was used extensively by the German army and is now being manufactured by R. F. Reed, Ltd., Barking, Essex; see also Nature, 153,707 ; 1944 and 154,795 ; 1944). Reference to a few additional members of the sulphonamide group of drugs is made under the headings of the infections for which they have been recommended. A section dealing with the relationships between penicillin and sulphonamide treatment is a useful addition to the memorandum. The spheres of action of these two forms of treatment overlap, and the notes given in this memorandum indicate the conditions which should be treated with sulphonamides and those for which penicillin, if it is available, should be used. The authors of the memorandum think that, when more penicillin can be obtained, it will replace sulphonamide more frequently, because it is usually more effective against infections which are also susceptible to sulphonamides. The memorandum states, for example, that penicillin has revolutionized the treatment of gonorrhcea, so that the instructions given for the sulphonamide treatment of this infection apply only when penicillin cannot be obtained or when the response to it has been unfavourable. A valuable minor feature of the memorandum is its list of the synonyms of the various sulphonamides.

\section{A Star Atlas for $20^{\circ}-40^{\circ} \mathrm{N}$.}

A STAR atlas, which has now run into the fourth edition, has been prepared by Dr. H. E. Hurst, M. R. Madwar and A. H. Samaha, and published by $R$. Schindler, Cairo. It contains six maps which enable readers to identify the stars visible in Egypt, North 
Africa, southern United States, China, northern India and the Middle East. Each map represents the sky at the same time of the night with intervals of two months, or, what amounts to the same thing, the sky on the same day with intervals of four hours. Full explanations are given for using these charts which, though constructed for latitude $30^{\circ} \mathrm{N}$., can be used also with sufficient accuracy for latitudes varying between $20^{\circ} \mathrm{N}$. and $40^{\circ} \mathrm{N}$. The local mean time of Cairo is used throughout, but the necessary correction for any other longitude can be easily made.

There is much useful information on other matters, such as a table of the constellations in which the planets appear, a list of the brightest stars, hints for identifying the stars, etc. One error should be corrected in the next edition. On p. 44 it is stated that the equation of time is the amount to be added to apparent solar time to give mean solar time, and the equation of time is given for the various months. The wrong signs are given in all cases and the equation of time, as given in the Nautical Almanac since 1931 , is apparent time minus mean time. The method of reckoning the equation of time as given in the "Star Atlas" is that in use prior to 1931.

\section{British Bryological Society}

A MeErrna of the British Bryological Society was held at Appleby, Westmorland, during April 10-17, under the presidency of Mr. W. R. Sherrin. Thirty-two members attended. Excursions were made to Cross Fell, High Cup Nick, Sunbiggin Tarn and other places in the neighbourhood. Among the many interesting bryophytes seen was the moss Schistostega pennata, which has not previously been found in Westmorland. During the meeting it was decided to enlarge and improve the Society's annual report and to embark on a scheme of co-operative observations on the season of production of sexual organs and sporogonia in various common bryophytes. It is hoped later to extend the scheme to other aspects of the biology of bryophytes.

\section{Bee-keeping}

Bulletrn No. 9, entitled "Bee-keeping" (London : H.M. Stationery Office. 9d. net), issued by the Ministry of Agriculture and Fisheries, has been entirely rewritten; the present issue is therefore a new publication that takes the place of its predecessor. Dr. C. G. Butler, apicultural expert on the staff of the Rothamsted Experimental Station, has been responsible for this booklet. It is intended as a short introduction to bee-keeping and is specially adapted for beginners, who will find a great deal of useful information compressed within its twenty-seven pages. It does not, however, take into account bee diseases and some other aspects of bee-keeping, which are being dealt with elsewhere.

\section{Atomes: A French Popular Journal of Science}

THE re-awakening of scientific studies in Franceor rather their emergence from the 'underground' where they were maintained with much difficulty and hazard during the German occupation-has been marked by the reappearance of well-known scientific journals. To these must now be added Atomes, an illustrated review published on the first of each month from 37 rue Caumartin, Paris IXe (30 francs; 300 francs a year). The purpose of the new journal as set out in an editorial note in the first issue (March) is to present to readers authoritative surveys of new scientific and industrial developments throughout the world. Most of the articles, it is hoped, will be written by distinguished French or foreign scientific workers, thus ensuring the accuracy so necessary for a journal of an educational character. The editor also intends that the journal shall be well illustrated. The first issue has articles by Prof. F. Joliot-Curie, Sir Robert Watson-Watt, Prof. S. Vavilov, Sir Howard Florey, with notes on current research and reviews of scientific books, and does not disdain to include some humour. Certainly, the promise of authoritative articles is well redeemed. The second issue includes among its contributors L. de Broglie, Prof. L. Binet and the head of the French television service. There are notes in both issues of French men of science who fell victims to the Germans. Atomes has made a good beginning; it is well illustrated and has an attractive coloured cover. The definition offered of a 'good article'-that it is one which informs the most learned and is understood by the layman-should lead to the best type of popularization. The new journal should play a very useful part in educating French readers in the developments and responsibilities of a scientific age.

\section{Assistant Agricultural Attaché in Washington}

Mr. P. J. MACFARLAN, deputy executive officer of the Northamptonshire War Agricultural Executive Committee, has been appointed assistant to the Agricultural Attaché to the British Embassy, Washington. Mr. Macfarlan was educated at Edinburgh Academy and the University of Glasgow. He continued his agricultural studies at the West of Scotland Agricultural College and the Dairy School for Scotland and was, in 1937, awarded a Ministry of Agriculture postgraduate scholarship. He became viceprincipal of the Chadacre Agricultural Institute in 1938, which post he held until the Institute was closed in 1940. Since then, he has been with the Northants War Agricultural Executive Committee, being appointed deputy executive officer in 1942.

\section{Announcements}

Prof. J. B. S. Haldane, Weldon professor of biometry in the University of London, has been awarded the degree of doctor of science honoris causa by the University of Groningen. The degree will be presented at the opening ceremony of the new university year on September 16.

WE are asked to state that Höber's "Physical Chemistry of Cells and Tissues", reviewed in Nature of February 2, p. 116, is published in the British Empire by Messrs. J. and A. Churchill, Ltd., 104 Gloucester Place, W.1.

OUR attention has been directed to a communication in Current Science (July 1940, p. 333) on the existence of an epiphysis in the pisiform bone of the young Old World langur (Semnopithecus entellus) by Prof. A. A. Ayer, of the Department of Anatomy, Andhra Med. ical College, Vizagapatam. Prof. Ayer describes the insertion of the flexor carpi ulnaris tendon into the epiphysis of the pisiform, and compares this with the insertion of the gastrocnemius into the epiphysis of the os calcis. This observation is of particular interest as it antedates the recent correspondence by Harris, Hughes, Haines and Eckstein in Nature $(153,715 ; 154,182 ; 1944)$. 